\title{
REKONSTRUKSI PENDIDIKAN ISLAM SEBAGAI UPAYA DALAM MEMBANGUN PERADABAN DUNIA
}

\author{
Oleh M. Suyudi ${ }^{1}$ \\ Dosen FTK UIN Sunan Ampel Surabaya DPK INSURI Ponorogo
}

\begin{abstract}
Abstrak
Tolok ukur maju atau tidaknya sebuah peradaban manusia adalah pendidikan. Pendidikan yang maju dan berkembang akan menghasilkan masyarakat yang maju dan berkembang pula, baik dalam teknologi maupun ilmu pengetahuan. Oleh karena itu, paradigma mengenai dikotomi antara ilmu agama dengan ilmu umum hendaknya di bongkar dan di fokuskan pada visi yang jelas dari umat Islam. Bagaimana menyiapkan generasi-generasi masa depan yang siap menghadapi tantangan global. Terkait hal tersebut pendidikan Islam yang menggabungkan pembelajaran dari aspek moral, spiritual maupun intelektual menjadi bagian penting dari proses pendidikan dalam membangun peradaban dunia.
\end{abstract}

Keyword: Pendidikan Islam, Globalisasi, Peradaban

\begin{abstract}
The benchmark of progress or not a human civilization is education. An advanced and developing education will produce an advanced and developing society, both in technology and in science. Therefore, the paradigm regarding the dichotomy between religious science and general science should be dismantled and focused on a clear vision of Muslims. How to prepare future generations who are ready to face global challenges. Related to this, Islamic education which combines learning from moral, spiritual and intellectual aspects is an important part of the educational process in building world civilization.
\end{abstract}

Keyword: Islamic Education, Globalization, Civilization

A. Pendahuluan

Pendidikan adalah fondasi utama dalam membangun peradaban dunia. Hal ini karena peradaban dunia dibangun di atas kekuatan manusia-manusia selaku pemegang kendali peradaban. Manusia yang mengalami kemajuan secara intelektual maupun moral akan dapat menciptakan peradaban yang kuat maju secara moril maupun materil.

${ }^{1}$ Dosen FTK UIN Sunan Ampel Surabaya DPK INSURI Ponorogo 
Terkait tujuan tersebut, maka rekonstruksi terhadap pendidikan Islam sebagai bagian dari upaya membangun keshalehan individual maupun sosial merupakan hal yang mutlak diperlukan. Hal ini terutama jika melihat wajah pendidikan Islam selama ini yang dibayang-bayangi oleh kemunduran, baik dari aspek materil maupun moril. Oleh karena itu reformulasi terhadap konsep pendidikan Islam harus segera dilaksanakan. Dengan demikian akan tercipta sumber daya manusia yang berkualitas sebagai pijakan dalam membangun peradaban yang maju dan berkembang.

Dalam makalah ini akan di diskusikan terkait pendidikan Islam sebagai modal investasi manusia dalam pembangunan peradaban dunia, serta strategi Islam dalam menghadapi tantangan global.

Jika melihat prosentasi jumlah penduduk di dunia, pada dasarnya jumlah pemeluk Islam di dunia cukup besar. Akan tetapi hal tersebut tidak dibarengi dengan peran signifikan dalam menentukan arah peradaban dunia. Hal ini berbeda dengan Yahudi misalnya yangjumlah pemeluknya hanya sekitar 50 juta yang tersebar di seluruh dunia , tetapi kemajuan ekonomi, politik dan ilmu pengetahuan tidak ada bandingannya dengan negeri muslim dimanapun. Hal ini dapat menjadi cermin bahwa kuantitas pemeluk agama Islam tidak berbanding lurus dengan kualitasnya. Oleh karena itu perlu upaya self criticism untuk melihat secara objektif kondisi umat Islam dan hal-hal yang mempengaruhi kemunduran peradaban Islam serta tantangan-tantangan global yang akan di hadapi oleh umat Islam.

B. Kondisi Umat Islam

Pada era modern saat ini, umat Islam telah tertinggal jauh dari Barat. Peradaban Barat mengalami kemajuan yang sangat signifikan pasca renaissance, baik dari aspek ilmu pengetahuan dan teknologi. Hal ini berbanding terbalik dengan kondisi umat Islam yang terus mengalami kemunduran pasca kejayaan Islam di era bani Abbasiyyah. ${ }^{2}$ Oleh karena itu penting untuk menganalisa akarakar permasalahan terkait penyebab-penyebab kemunduran umat Islam. Adapun di antara penyebab kemunduran umat Islam yaitu:

1. Umat Islam terpecah belah dan diskonsolidasi. Hal tersebut di antaranya dipengaruhi oleh adanya hadits yang menyebutkan bahwa umat Islam akan terbagi menjadi tujuh puluh tiga golongan dan yang selamat hanya satu.

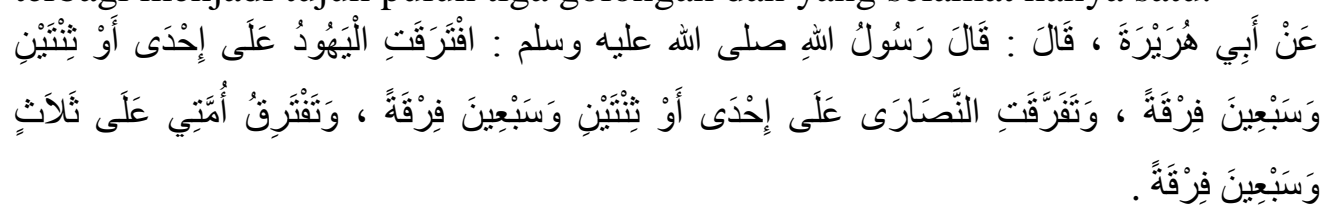

${ }^{2}$ Makhmud Syafe'i, Pengantar dalam Perkembangan Modern Dunia Islam, (Bandung: CV Yasindo Multi Aspek dan Value Press Bandung, 2008) 
Artiya: Dari Abu Hurairah ia berkata: Rasulullah saw telah bersabda: Kaum Yahudi telah terpecah menjadi tujuh puluh satu (71) golongan atau tujuh puluh dua (72) golongan, dan kaum Nasrani telah terpecah menjadi tujuh puluh satu (71) atau tujuh puluh dua (72) golongan, dan ummatku akan terpecah menjadi tujuh puluh tiga (73) golongan.

Hadis tersebut seolah menjadi alasan normatif bagi umat Islam untuk tidak bersatu. Dan dijadikan alasan untuk mengutuk, menyesatkan, mengkafirkan dan menyerangorang lain. Oleh karena itu sinergitas antar kelompok tidak lagi tampak dan yang muncul adalah egoisme kelompok. Seolah hanya kelompoknya sendiri yang paling benar.

2. Umat Islam terpenjara oleh kesadaran magis (tahayul). Mereka terlena dengan kesadaran magic. Dalam pandangan mereka, setan adalah musuh yang nyata. Oleh karena itu, bayangan umat Islam tentang sosok setan adalah makhluk halus yang suka membuat orang kesurupan atau hantu. Padahal manusia juga bisa menjadi setan yang tingkah lakunya bisa jauh lebih dahsyat efeknya bagi kehidupan. Sebagai contoh yaitu perilaku manusia yang suka menindas orang atau kelompok lain, negara yang sewenang-wenang terhadap negara lain, majikan yang suka memeras buruhnya, penguasa yang dzalim terhadap rakyatnya, dan perilaku-perilaku serupa yang merugikan orang lain. Realitas ini jauh berbeda dengan Negara barat yang di dominasi kesadaran kritis dan kemajuan dalam ilmu pengetahuan dan teknologi.

3. Umat Islam memiliki strategi gerakan yang lemah dalam pengembangan sumber daya manusia. Program pemberdayaan masyarakat, advokasi terhadap mereka yang tertindas atau penguatan ekonomi serta politik umat belum terprogram secara lebih matang. Pola-pola gerakan yang dilakukan masih bertahan pada pola konvesional dan anti kemajuan. Berbeda dengan kondisi di Barat yang melampaui modernitas, baik dari aspek ekonomi, hukum maupun politik. 


\section{Islam dan Tantangan Global}

Pada dasarnya Umat Islam dewasa ini di hadapkan pada era globalisasi. Globalisasi merupakan suatu proses pengintegrasian ekonomi nasional bangsa bangsa ke dalam suatu sistem ekonomi global. ${ }^{3}$ Globalisasijuga merupakan proses kebudayaan yang ditandai dengan adanya kecenderungan untuk menyeragamkan wilayah-wilayah di dunia, baik geografis maupun fisik, dalam format sosial, budaya, ekonomi, dan politik. Dalam kehidupan sosial, proses global telah menciptakan egalitarianisme, di bidang budaya memicu munculnya internationalization of culture, di bidang ekonomi memunculkan revolusi teknologi media informasi dan transportasi serta menciptakan saling ketergantungan dalam proses produksi dan pemasaran, dan di bidang politik menciptakan liberalisasi. ${ }^{4}$ Adapun tantangan umat Islam oleh adanya proses globalisasi dapat di gambarkan dalam beberapa hal berikut.

1. Munculnya "Neo-Imperialisme" dibidang ekonomi, politik, kebudayaan dan peradaban. Hal tersebut merupakan kelanjutan dari Imperialisme fisik oleh Negara Barat. Neo-imperialisme tersebut berimbas pada budaya lokal dan nasional yang tercerabut akarnya, sehingga jati diri bangsa dan nilai-nilai agama yang tumbuh dan berkembang di tengah masyarakat dapat tergeser dengan sendirinya oleh budaya Barat seperti liberalisasi, kapitalisasi dan lain sebagainya.

2. Adanya Clash of Civilization (benturan peradaban) antara peradaban barat dan timur. Hal ini disebabkan oleh proses globalisasi oleh Negara Barat yang menyentuh peradaban Timur. Kepentingan Barat adalah dominasi terhadap seluruh negara di Timur, baik dari segi ekonomi, sosial, politik, ilmu pengetahuan maupun teknologi. Dari aspek ilmu pengetahuan, hegemoni Barat terlihat jelas ketika kaum terdidik di negara berkembang dengan setia dan tidak sadar menyebarkan dan membela nilai-nilai dan institusi Barat, seperti liberalisasi, kapitalisasi dan demokrasi. Semua yang datang dari Barat

\footnotetext{
${ }^{3}$ Mansour Fakih,Sesat Pikir TeoriPembangunan dan Globalisasi(Yogyakarta:Insist Press, 2001), 211.

${ }^{4}$ Moh Ali Aziz, Tantangan Pendidikan Islam di era Global, Jurnal Tarbawiyah Program Pascasarjana STAI al-Khozini,2
} 
diterima sebagai nilai-nilai universal dan di anggap sebagai produk peradaban terbaik yang harus diikuti.

3. Isu Terrorisme yang ditujukan terhadap umat Islam. Hal tersebut merupakan upaya Amerika Serikat dan sekutunya untuk menyerang kelompok-kelompok Islam yang dinilai radikal dengan dalih memberantas terorisme. Islam dianggap sebagai ancaman bagi ideologi kebebasan yang tumbuh subur di dunia Eropa dan Amerika. Islam dianggap ancaman karena Islam bukan hanya sebagai sebuah agama, namun lebih kepada ideologi atau cara pandang hidup (way of life) umatnya. Jika hal tersebut didiamkan maka akan bepotensi merusak ideologi Amerika dan Eropa. Adapun bentuk perlawanan Amerika terhadap terorisme di antaranya yaitu Agresi Amerika Serikat diAfganistan dan Irak. ${ }^{5}$

D. Globalisasi dan Pengaruhnya di Level Lokal Maupun Nasional

Arus globalisasi pada dasarnya berimbas dan berpengaruh pada banyak hal, baik pengaruh positif maupun negative, baik di tingkat local maupun nasional. Adapun dampak positif dari globalisasi di antaranya yaitu:

1. Meningkatnya etos kerja, kedisiplinan, kemandirian, rasionalitas, sportifitas, dan lain sebagainya.

2. Kemajuan di bidang teknologi. Hal tersebut berimbas pada kehidupan sosial ekonomi lebih produktif, efektif, dan efisien sehingga membuat produksi dalam negeri mampu bersaing di pasar internasional.

3. Pasar untuk produk dalam negeri semakin luas.

4. Kemajuan di bidang teknologi, komunikasi, informasi, dan transportasi yang memudahkan kehidupan manusia.

5. Mudah memperoleh informasi dan ilmu pengetahuan. ${ }^{6}$

Adapun dampak negatif dari globalisasi di antaranya yaitu:

1. Meningkatnya jumlah manusia, akan tetapi tidak di imbangi dengan SDM yang memadai, sehingga mayoritas jumlah tetapi minim peran. Yang kaya

\footnotetext{
${ }^{5}$ http://news.unpad.ac.id/?p=13351

${ }^{6} \mathrm{http}: / /$ asrilrahmatp.blogspot.com
} 
akan semakin kaya, yang miskin akan semakin terpinggirkan. Terutama jika yang berkuasa adalah kelompok kapitalis.

2. Adanya demoralisasi, yaitu gelombang dekadensi moral. Hal ini disebabkan karena semakin mudahnya nilai-nilai budaya Barat yang masuk ke Indonesia baik melalui internet, media televisi, maupun media cetak yang banyak ditiru oleh masyarakat. Gelombang liberalisasi moral tersebut sering dihadapi secara parsial, tidak komprehensif. Ini adalah problem budaya yang harus dihadapi dengan counter hegemonic culture (melawan budaya dominan), dan tidak semata-mata persoalan split personality (ketidak shalihan individu).

3. Berkubang dalam konflik. Dampak dari politik pecah belah yang dilakukan Barat pada dasarnya berdampak sampai di tingkat grassroot. Bentuk dampak tersebut antara lain yaitu munculnya sikap saling curiga terhadap kelompok lain. Selain itu hal-hal yang semestinya bukan ajang konflik, menjadi media efektif untuk menyulut konflik.Terutama jika memasuki wilayah politik, maka akan sangat rawan terjadi konflik, bahkan berpotensi terjadi kerusuhan.

\section{E. Solusi Strategis Dalam Men-Counter Efek Negatif dari Globalisasi}

Sebagaimana yang telah di bahas sebelumnya, Globalisasi memiliki efek negative yang menyangkut SDM masyarakat, demoralisasi maupun konflikkonflik antar kelompok yang berpotensi untuk terjadi. Oleh karena itu, perlu adanya solusi strategis dalam men-counter arus negative globalisasi. Di antara solusi strategis tersebut yaitu:

1. Rekonsolidasi. Hal tersebut meliputi konsolidasi pemahaman dan konsolidasi gerakan. Artinya, perlu diupayakan adanya sinergitas antara pemahaman dan gerakan masyarakat. Dengan demikian, upaya tersebut dapat meminimalisir adanya gesekan dan pertentangan, meskipun antara kelompok bergerak dengan cara dan strateginya sendiri.

2. Membangun ekonomi dan kesejahteraan sosial umat Islam. Hal tersebut dapat dilakukan dengan pengelolaan zakat, infaq dan shadaqah untuk pemberdayaan masyarakat. Selain itu ekonomi Islam juga perlu digerakkan agar umat bebas dari dampak kapitalisme yang sarat riba dan penuh nuansa 
perjudian. Upaya ini penting untuk mengangkat derajat kesejahteraan umat sehingga umat lebih terberdaya dalam konteks kehidupan kekinian yang persoalannya semakin komplek.

\section{F. Pendidikan Islam Berwawasan Global Sebagai Upaya Rekonstruksi Peradaban}

Melakukan pembaruan sistem pendidikan Islam. Hal tersebut merupakan salah satu upaya untuk menangkal pengaruh globalisasi. Hal itu dikarenakan maju mundurnya atau baik buruknya suatu bangsa akan ditentukan oleh keadaan pendidikan yang dijalani oleh bangsa itu. ${ }^{7}$ Adapun jika melihat kondisi pendidikan saat ini yang tampak adalah adanya dikotomi pendidikan, yaitu pendidikan agama dan pendidikan umum. Sistem pendidikan dikotomis semacam ini terbukti telah gagal melahirkan manusia yang berkepribadian luhur dan saleh sekaligus mampu menjawab tantangan perkembangan melalui penguasaan sains dan teknologi di era globalisasi saat ini.

Terkait hal itu perlu upaya pembaharuan dalam system pendidikan Islam. Terutama jika melihat bahwa kondisi pendidikan Islam sekarang sangat ketinggalan dengan lembaga pendidikan lainnya. Hal tersebut antara lain di sebabkan oleh beberapa hal: Pertama, pendidikan Islam sering terlambat merumuskan diri untuk merespons perubahan dan kecenderungan masyarakat sekarang dan akan datang. Kedua, Sistem pendidikan Islam kebanyakan masih cenderung mengorientasikan diri dibidang-bidang humaniora dan ilmu-ilmu sosial. Ketiga, usaha pembaharuan pendidikan Islam sering bersifat sepotongsepotong dan tidak komprehensif sehingga tidak terjadi perubahan yang esensial. Keempat, pendidikan Islam tetap berorientasi pada masa silam ketimbang berorientasi kepada masa depan, atau kurang bersifat future oriented. Kelimasebagian pendidikan Islam belum dikelola secara professional, baik dalam tenaga pengajar, kurikulum maupun pelaksanaan pendidikannya.

Selain itu saat ini kita juga dihadapkan pada sebuah kenyataan bahwa pendidikan Islam tidak berdaya dalam realitas masyarakat industri dan teknologi

\footnotetext{
${ }^{7}$ Abdul Khobir, Pendidikan Agama Islam di Era Globalisasi, Forum Tarbiyah, Vol 7, no $1,2009,2$
} 
modern. Kenyataan itu didukung oleh pandangan ekstrim dari sebagian umat Islam yang kurang meminati ilmu-ilmu umum dan bahkan sampai ke tingkat “diharam-kannya". Hal ini tentu saja berdampak pada pembelajaran dalam sistem pendidikan Islam yang masih berkutat pada teks. Pendidikan hanya bergelut dengan setumpuk teks-teks keagamaan yang sebagaian besar berbicara seputar hukum-hukum Islam (fiqh) semata. Dengan demikian, terjadinya krisis pendidikan Islam dikarenakan penyempitan terhadap pemahaman pendidikan Islam. Pendidikan Islam dimaknai hanya berkisar pada aspek kehidupan ukhrawi yang terpisah dari kehidupan duniawi, atau aspek kehidupan rohani yang terpisah dari kehidupan jasmani.

Terkait hal tersebut, maka perlu membangun paradigma baru dalam pendidikan Islam, dimana pendidikan Islam hendaknya berorientasi pada pengembangan dengan ciri desentralistis, kebijakan pendidikan bersifat bottom up, orientasi pengembangan pendidikan lebih bersifat holistic; artinya, pendidikan ditekankan pada pengembangan kesadaran untuk bersatu dalam kemajemukan budaya, kemajemukan berpikir, menjunjung tinggi nilai moral kemanusiaan dan agama, kesadaran kreatif, produktif, dan kesadaran hukum. Demikian pula dengan meningkatkan peran serta masyarakat secara kualitatif dan kuantitatif dalam upaya pengembangan pendidikan, pemberdayaan institusi masyarakat, seperti keluarga, LSM, pesantren, dan dunia usaha. ${ }^{8}$

Upaya membangun pendidikan Islam berwawasan global dengan menerapkan paradigma baru dalam pendidikan Islam tersebut tentu saja bukan persoalan mudah, karena pada waktu bersamaan pendidikan Islam harus memiliki kewajiban untuk melestarikan, menanamkan nilai-nilai ajaran Islam dan di pihak lain berusaha menanamkan karakter budaya nasional dan budaya global. Meskipun demikian, upaya membangun pendidikan Islam yang berwawasan global dapat dilaksanakan dengan langkah-langkah yang terencana dan strategis. Pertama, persoalan konsep dualisme dikotomi pendidikan harus segera ditumbangkan dan dituntaskan, baik pada tataran filosofis-paradigmatik maupun

\footnotetext{
${ }^{8}$ Muh Sain Hanafy, Paradigma Baru Pendidikan Islam Dalam Upaya Menjawab Tantangan Global, Lentera Pendidikan, Vol 12, no 2, 2009, 181.
} 
teknis departemental. Kedua, persoalan integrasi ilmu dan agama dalam satu sistem pendidikan ini memang tidak mudah, melainkan harus atas dasar pemikiran filosofis yang kuat. Ketiga, mengadakan upaya perubahan sistem pendidikan yang dirumuskan dalam kerangka dasar filosofis pendidikan, tentu saja dengan melalui pembenahan kurikulum yang kuat dan matang. Rumusan paradigma pendidikan serta strategi perencanaan tersebut paling tidak memberikan arah sesuai dengan arah pendidikan, yang secara umum dituntut mengantarkan masyarakat menuju masyarakat yang religius, demokratis, dan tangguh menghadapi lingkungan global.

G. Penutup

\section{Kesimpulan}

Globalisasi adalah suatu kondisi atau keadaan yang tidak bisa hindari, dimana seiring perkembangan zaman, ilmu pengetahuan dan teknologi semakin mengalami perkembangan dan kemajuan. Hal tersebut kemudian memunculkan pengaruh positif maupun negatif dalam kehidupan manusia. Terkait hal tersebut, hal yang perlu dilakukan adalah mempersiapkan sumber daya manusia yang dinamis dan siap dalam menghadapi tantangan global. Oleh karena itu, pendidikan Islam yang berprinsip pada pembentukan moral (akhlak) dan intelektual (ilmu pengetahuan) menjadi solusi dalam merespon arus global. Dengan demikian, paradigma pendidikan Islam yang berwawasan global menjadi langkah utama dalam menyiapkan generasi-generasi masyarakat yang lebih produktif dan siap menghadapi hantaman globalisasi.

\section{Saran}

Terkait uraian di atas dapat di uraikan beberapa saran sebagai berikut:

1. Umat harus bersatu, tidak tercerai berai walaupun berada dalam berbagai kelompok gerakan

2. Umat harus maju, tidak terkungkung oleh kesadaranmagis, tetapi terus berupaya untuk belajar dan mengakaji ilmu pengetahuan dan teknologi.

3. Umat yang gemar untuk membantu sesama saudaranya yang membutuhkan, sehingga masing-masing umat mendapat kesempatan untuk mengakses pendidikan sebagai bekal memberantas kebodohan umat. 
4. Umat yang sederajat, tidak ada lagi umat yang merasa lebih unggul dari yang lain, yang masing-masing dapat bersinergi dalam memperjuangkan Islam.

\section{DAFTAR PUSTAKA}

Abdul Hafidz, Muhammad Nur, 1997, Mendidik Anak Bersama Rasulullah ,Al-Bayan, Bandung.

Abdul Khobir, 2009, Pendidikan Agama Islam di Era Globalisasi, Forum Tarbiyah, Vol 7, no 1,

Al-Attas, Syed M. Naquib, 2003, Filsafat dan Praktik Pendidikan Islam, Mizan, Bandung

An-Nahlawi, Abdurrahman, 1995, Pendidikan Islam di Rumah, Sekolah dan Masyarakat, Gema Insani Press, Jakarta.

Catatan Kang Jalal (Visi Media, Politik dan Pendidikan, Mizan, Bandung.

Darmaningtyas, 2005, Pendidikan Rusak-Rusakan, LKiS Pelangi Aksara, Yogyakarta.

Daud Ibrahim, Marwah, 1994, Teknologi, Emansipasi dan Transendensi (Wacana Peradaban dengan Visi Islami), Mizan, Bandung.

F. O'neil, William, 2001, Ideologi-Ideologi Pendidikan,Pustaka Pelajar, Yogyakarta.

Fadjar, Malik, 1999, Reorientasi Pendidikan Islam, Fajar Dunia, Jakarta.

Freire, Paulo, 1999, Politik Pendidikan (Kebudayaan, Kekuasaan dan Pembebasan), Pustaka Pelajar, Yogyakarta.

Ismail, (ed), 2000, Pendidikan Islam, Demokratisasi dan Masyarakat Madani, Pustaka Pelajar, Yogyakarta.

Latif, Yudi, 2005, Inteligensia Muslim dan Kuasa (Geneologi Intelgensia Muslim Indonesia Abad ke 20), Mizan, Bandung. Ma"earif, Syafii, A., dkk, 1991,

Makhmud Syafe'i, 2008, Pengantar dalam Perkembangan Modern Dunia Islam, (Bandung: CV Yasindo Multi Aspek dan Value Press Bandung, )

Mansour Fakih, 2001, Sesat Pikir TeoriPembangunan dan Globalisasi(Yogyakarta:Insist Press,),

Moh Ali Aziz, Tantangan Pendidikan Islam di era Global, Jurnal Tarbawiyah Program Pascasarjana STAI al-Khozini 
Muh Sain Hanafy, 2009, Paradigma Baru Pendidikan Islam Dalam Upaya Menjawab Tantangan Global, Lentera Pendidikan, Vol 12, no 2

Mukti, Abdul, 2000, (editor), Pendidikan, Demokratisasi dan Masyarakat Madani, Pustaka Pelajar, Yogyakarta.

Nata, Abuddin, 2000, Pemikiran Para Tokoh Pendidikan Islam, Raja Grafindo Persada, Jakarta.Rahmat, Jalaluddin, 1997,

Shihab, Quraisy, 1996, Wawasan Al-Qur'an (Tafsir Maudhu'i atas Pelbagai Persoalan Umat), Mizan, Bandung.

Soebahar, Abd. Halim, 2002, Wawasan Baru Pendidikan Islam, Kalam Mulia, Jakarta.

Tafsir, Ahmad, 1994, Ilmu Pendidikan dalam Perspektif Islam, Remaja Rosda Karya, Bandung. 